\title{
Leiomyosarcoma and Endometrial Stromal Sarcoma pT1 TNM Finding v7
}

National Cancer Institute

\section{Source}

National Cancer Institute. Leiomyosarcoma and Endometrial Stromal Sarcoma pT 1 TNM

Finding v7. NCl Thesaurus. Code C89586.

Tumor limited to the uterus. (from AJCC 7th Ed.) 